\title{
De Londres a Washington, da cidadania à soberania nacional: o antirrepublicanismo, o pan-americanismo e o "projeto" de Joaquim Nabuco
}

\author{
Marcus Vinícius Gomes Caixeta \\ Orientador: Sergio Barreira de Faria Tavolaro \\ Dissertação de Mestrado \\ Data da defesa: 30.03.2012
}

\begin{abstract}
ste trabalho analisa a trajetória de Joaquim Nabuco, com vistas a compre- ender os termos de sua conversão republicana e de sua adesão à causa do pan-americanismo. Para tanto, foca sua atuação política e intelectual, desde sua entrada na Academia de Direito, em 1866, até sua morte, em 1910. Conclui que a defesa da aproximação entre Brasil e Estados Unidos deve ser compreendida a partir de uma mudança de ênfase nas preocupações de Nabuco, as quais se transferem da construção da cidadania para a proteção à soberania nacional. A mudança, longe de representar um desvio, visa a continuidade de seu projeto de construção e desenvolvimento do Estado Nacional.
\end{abstract}

Palavras-chave: Sociologia, Pensamento Social Brasileiro, Cidadania, Pan-americanismo, Joaquim Nabuco. 